as to be under the influence of a magnetic field, is broken up into two circular components oppositely polarised:

The system used consisted of two rectangular prisms of glass placed with their diagonal faces parallel and separated by a plate of mica of approximately $\frac{1}{4} \lambda$ retardation. The lines of force were parallel to this plate. A ray of ordinary light from a sodium flame sent into the system normal to this plate was successively totally reflected parallel to the lines of force and then at right angles to the mica, which served to change the phase and to keep the absolute direction of the circular vibrations the same. The rays passed five times around within this system, giving twenty internal reflections.

The separation of the rays agreed, so far as could be determined, with the calculations based on the assumptions usualiy made in explaining this phenomenon. When the field was reversed, the direction of vibration of each circular component was reversed. This does not establish the assumption of a relative change in the velocities usually made, as a relative change in the phase of the components, or both, would produce the same effect. It does show, however, that a medium in a magnetic field transmits, in the direction of the lines of force, light vibrations by circular components only. D. B. BRACE.

Physical Laboratory, University of Nebraska, August I.

\section{Physical Structure of Asbestos.}

CAN any of your readers tell me where I can find a good account of asbestos and its physical structure? The ordinary works of reference I am acquainted with give too meagre an account to be of any use.

I3 Hampton Road, Bristol, August I.

\section{THE BRADFORD MEETING OF THE BRITISH ASSOCIATION.}

$I^{T}$

is now possible to give a forecast of the chief subjects to be brought before the various Sections of the British Association at the forthcoming Bradford meeting. The following outlines of sectional programmes show that many matters of importance and wide scientific interest will be dealt with, so that the Bradford meeting promises to be a memorable one. No particulars as to the probable proceedings of the Physics Section have yet been received.

\section{Chemistry.}

Prof. W. H. Perkin, jun., F.R.S., the President of Section B (Chemistry) is this year setting a precedent in the conduct of the sectional meetings. Several members of the Association have been asked to furnish reports on the present state of knowledge in the particular departments of chemistry with which they are especially conversant, and the reading of these reports will be followed by discussion.

In accordance with this programme, Mr. Francis $\mathrm{H}$. Neville, F.R.S., will present a report dealing with the properties and interactions of the metals. The following questions will be brought forward for discussion in connection with the report :-

I. Are the methods usually employed in studying the equilibrium between two or more substances with change of temperature immediately applicable to the study of alloys, and are similar results obtained in the two cases? Thus, with varying conditions of temperature and concentration, a system of ferric chloride and water deposits (I) ice ; (2) $\mathrm{Fe}_{2} \mathrm{Cl}_{6}, 12 \mathrm{H}_{2} \mathrm{O}$; (3) $\mathrm{Fe}_{2} \mathrm{Cl}_{6}, 7 \mathrm{H}_{2} \mathrm{O}$; (4) $\mathrm{Fe}_{2} \mathrm{Cl}_{6}, 5 \mathrm{H}_{2} \mathrm{O}$; (5) $\mathrm{Fe}_{2} \mathrm{Cl}_{6},{ }_{4} \mathrm{H}_{2} \mathrm{O}$; (6) $\mathrm{Fe}_{2} \mathrm{Cl}_{6}$ or (7) mixtures of the phase numbered $n$ with that numbered $(n+\mathrm{I})$ ? Are the solubility curve of ferric chloride and the freezing point curves of metallic mixtures of the same kind?

2. How far does (I) microscopic examination, and (2) change in physical properties, such as electromotive force, \&c., enable us to detect the existence of a compound in an alloy?

$$
\text { NO. I607, voL. } 62]
$$

3. In what definite proportions are metals known to combine? Is any regularity manifest with respect either to their position in the periodic system or to their valency with regard to non-metals?

4. What methods are available for determining the molecular weights of the metals, and can it be asserted in any cases, other than those of mercury, zinc and cadmium, that the molecular weight is satisfactorily determined?

5. Can a definition be given of a metallic element which makes it possible to distinguish between metals and non-metals?

6. Can any explanation be given which will satisfactorily account for ( 1 ) the difference between metallic and electrolytic conduction, and (2) the remarkable changes in the electrical conductivity of metals attending admixture?

As some of the questions bearing upon this subject are of as great importance to the physicist as to the chemist, physical members of the Association are to be invited to join in the discussion. Dr. Adolf Liebmann will contribute a report on recent improvements in the treatment of textiles, a subject which acquires peculiar importance from the fact that the 1900 Meeting of the Association is being held in the centre of a district devoted to the textile industry. Dr. Arthur Lapworth will give a report on our knowledge of the chemistry and constitution of camphor. Attention has of late years become so concentrated on the chemistry of the camphor group as to make an authoritative discussion on the constitution of camphor almost a necessity to the organic chemist. Mr. William J. Pope will present a report on our present knowledge of stereochemistry ; it is understood that special attention will be given in this report to the work done during the past twelve months on the optical activity of compounds containing an asymmetric nitrogen, tin or sulphur atom. Among the other papers to be presented at the meeting is one on the specific heat of gases at temperatures above $400^{\circ}$, by Prof. H. B. Dixon, F.R.S. ; and Mr. H. T. Brown, F.R.S., will give an account of his recent work on the diffusion of gases and liquids. The papers of special local interest include one on the treatment of Bradford sewage, by Mr. F. W. Richardson, the City analyst; and also a paper on the treatment of woolcombers' effluents, by Mr. W. Leach. The title of the sectional address to be delivered by the President is, of course, not yet announced ; it is understood, however, that the address will deal with the teaching of chemistry.

\section{GEOLOGY.}

The proceedings of Section C (Geology) will open at I0.30 a.m. on Thursday, September 6, with the delivery of the address of its president, Prof. W. J. Sollas, who has chosen for his subject, "The History of the Earth in relation to a Scale of Time." Prof. Sollas will take a wide scope in discussing this subject, and will introduce such fundamental matters as the constitution of the earth, the relative value of the various geological periods, the origin of ocean basins, the formation of mountainchains, and the evolution of the organic world. We may be sure that his discourse will be brilliant and suggestive. It is probable that Prof. J. Joly will also treat on the knotty problem of the duration of geological time at the same, or a subsequent, meeting of the Section.

As befits the place of meeting, the geology of the Carboniferous rocks will receive much attention. A joint discussion with the botanists (Section $\mathrm{K}$ ), on the conditions which existed during the growth of the forests of the Coal Period, will be held on Monday, September ro, when Mr. A. Strahan and Mr. J. E. Marr will open the debate from the geologist's standpoint. The Coalmeasures of the West Riding form the subject of a paper by Mr. W. Cash, and those of North Staffordshire of one 
by Mr. W. Gibson, of H.M. Geological Survey ; while the fossil fishes of the Carboniferous rocks will be discussed by Dr. E. D. Wellburn. Prof. W. B. Scott has promised a paper, with lantern illustrations, on the geology and palæontology of Patagonia, which promises to be of great interest. Prof. A. P. Coleman, of Toronto, brings forward an account of a ferriferous horizon in the Huronian of Lake Superior, and will also present the final report of the Committee for the investigation of Pleistocene deposits in Canada. Mr. J. J. H. Teall will describe a plutonic complex of Sutherland, and its bearing on current hypotheses as to the genesis of igneous rocks. Glacial subjects, as usual, will receive due attention; papers on the local phenomena will be brought forward by Dr. Monckman and Messrs. Muff, Jowett and others, and on those of Welsh localities by Mr. E. Greenley and Mr. J. R. Dakyns. The concretions of the magnesium limestone of Durham will be discussed by Dr. Abbott. Tidal ripple-marks will be described by Mr. Vaughan Cornish ; and the caves and pot-holes of Ingleborough and district by their explorer, Mr. S. W. Cuttriss, in both cases with lantern illustrations. Mr. A. C. Seward will treat of the Jurassic flora of the Yorkshire coast. Among the reports of committees will be that which deals with the course taken by underground waters in the Ingleborough district, giving the result of recent experiments; and excursions have been arranged to the sites of the investigation. As usual, short afternoon sectional excursions to places of geological interest in the neighbourhood of Bradford will be included in the arrangements of the Section.

\section{Zoology (AND Physiology).}

Dr. R. H. Traquair, F.R.S., the President of Section D (Zoology and Physiology), will address the Section on "The Bearings of Fossil Ichthyology on the Doctrine of Descent." Major Ronald Ross will (by request) address the Section on "Malaria and Mosquitoes." Messrs. Gamble and Keeble will give an account of their researches on the "Colour-Physiology of Hippolyte," illustrated by lantern projections and practical demonstrations. Prof. L. C. Miall, F.R.S., will read a paper on the "Respiration of Aquatic Insects"; and other papers on the natural history of insects will be given by Messrs. T. H. Taylor, Wilkinson, Walker, and Dr. Munro. Prof. S. J. Hickson, F.R.S., will read a paper on "The Nuclei of Dendrocometes." Among the reports of committees, Mr. Stanley Gardiner's account of his researches on the Coral Islands of the Indian Ocean is awaited with particular interest.

\section{GEOGRAPHY.}

In Section E (Geography), the President, Sir George Robertson, will deliver his address on Thursday, September 6, at in a.m. The subject of the address is appropriately "Geography and the Empire." Amongst the subjects to which special attention will be directed in the Section may be mentioned that of "Colonial and Foreign Surveys." Papers dealing with these will be read by Mr. E. G. Ravenstein and Mr. B. V. Darbishire ; and Dr. H. R. Mill will contribute a paper on "The Treatment of Regional Geography." Problems of applied commercial geography will be dealt with by Mr. G. G. Chisholm in a paper on "Some Consequences that may be Anticipated from the Development of the Resources of China," and Mr. E. Heawood on the "Commercial Resources of Africa."

An important paper on "Railway connection between Europe and Asia" will be contributed by Sir Thomas Holdich; and it is hoped that Mr. C. R. Beazeley will return in time to give an account of his journeys on the recently-opened portions of the Siberian Railway.

The excellent work initiated by Mr. T. G. Rooper while H.M. Inspector of Schools at Bradford, it NO. I 607 , VOL. 62 ] carried on by Mr. E. R. Wethey, one of the secretaries of the Section, makes papers on "School Geography," and the teaching of elementary geography generally, of special interest at this meeting. Mr. Rooper and Mr. Wethey will each describe parts of their work, and will exhibit some of the maps and models used as illustrations, in the exhibition which forms a novel feature of the Bradford meeting.

In the department of geographical exploration, $\mathrm{Mr}$. C. E. Borchgrevink will give an account of the voyage of the Southern Cross in the Antarctic regions. Captain H. P. Deasy will describe his journeys in Central Asia ; Captain E. S. Grogan contributes a paper, "Through Africa from the Cape to Cairo"; and Mr. Cutliffe Hyne one on "Arctic Lapland."

On special and more technical subjects there will be papers on "Large Earthquakes in I899," by Prof. John Milne; on the "Distribution of Relative Humidity," by Mr. E. G. Ravenstein ; on "Snow Ripples," by Mr. Vaughan Cornish ; and on "The Origin of Moels," by Mr. J. E. Marr.

\section{MeChanical SCIENCE.}

Sir Alexander Binnie, the President of Section G (Mechanical Science), will survey the various stages of scientific progress which have led to the modern conception of natural phenomena. Several interesting papers by local engineers will be read before the Section. One, by Mr. J. Watson, will describe the Bradford waterworks and the very fine reservoirs belonging to that system. In connection with this there will be an excursion on the Saturday to the reservoirs. A paper will be read by Prof. Hele-Shaw on the resistance of road vehicles to traction. A proposal will be made to appoint a committee of the Association to carry out an exhaustive series of experiments on road resistance. Much interest will no doubt be excited by the paper which is to be read by Mr. J. H. Glass on the coal and iron ore fields at Shansi and Honan, and railway construction in China. This paper will be illustrated by a number of lantern slides showing the Chinese methods of working these mineral deposits. In view of the great industry of Bradford, the paper by Prof. Beaumont on the application of photography to textile designing is likely to create great interest. In the department of electrical engineering there is a good programme of papers. The Small Screw Gauge Committee will submit a report descriptive of a series of experiments which have been carried out by Mr. Price in the engineering laboratory at University College, London; and in connection with this, a paper will be read by Mr. O. P. Clements on screw threads used in cycle construction and for screws subject to vibration. Mr. A. Mallock will give an account of experiments he has made to determine the tractive force, resistance, and acceleration of electric trains. Mr. Aldridge's paper on the automobile for electric street traction will describe a novel process, by means of which, in certain circumstances, it is possible to organise a tram service without tram rails, and this paper will be illustrated by the cinematograph, showing an actual system at work.

\section{ANTHROPOLOGY.}

In the Anthropological Section, the President, Prof. J. Rhys, proposes to devote his opening address to "the prehistoric ethnology of the British Isles," a subject full of matter for discussion, on which he is entitled to speak with peculiar authority. Several important papers are expected in the department of anthropometry, especially a note by Dr. Beddoe on the "vagaries of the Cephalic Index," and a paper by Prof. Cunningham on the "Sacral Index." Mr. H. Ling Roth contributes a classification of various modes of ornamenting the skin, such as tattooing, cicatrisation, and 
the like. Dr. Haddon promises an account of his recent visit to Borneo, with special reference to the industries and daily life of the natives. A discussion is being arranged on the subject of "Animal Worships," with reference to the vexed question of the significance of totemism; and Mr. David Boyle, of Toronto, will contribute a study of the phenomena of Neo-Paganism among the natives of certain parts of the Dominion of Canada. Among other archæological papers, special interest attaches to Mr. Arthur Evans's account of his recent discovery of tablets inscribed with an Ægean script, in the Mycenæan palace of Gnossus in Crete; and to Mr. F. Ll. Griffith's discussion of the origin of the Egyptian hieroglyphic system. There will be papers, as usual, on objects of archæological interest in the neighbourhood of Bradford.

\section{BOTANY.}

Prof. Vines, the President of Section K (Botany), in his address on Thursday, September 6, will take as his subject the progress of botany in the nineteenth century. It has been arranged to hold a joint discussion with some of the members of the Geological Section on the conditions under which the forests of the Coal Period grew. The origin and manner of formation of Coal, the climatic and physical conditions which prevailed during the deposition of the Coal-measures, the most striking characteristics of the vegetation, and other questions will probably be dealt with. The local committee propose to form a small museum of specimens and photographs to illustrate the botany and geology of the Coal Period.

On Friday afternoon a semi-popular lecture, illustrated by lantern slides, will be delivered by Mr. Percy Groom, on "Plant-form in relation to nutrition."

Among the papers already promised, the following may be mentioned :-On the presence of seed-like organs in certain Palæeozoic Lycopods, by Dr. D. H. Scott ; the origin of modern Cycads, by Mr. Worsdell ; the fertilisation of Caltha palustris, by Miss Thomas; on a new type of transition from stem to root in seedlings, by Miss Sargant ; the anatomy of the stem of Angiopteris evecta, by Miss Shove; the structure of the nucleolus, also a demonstration of the structure of the eye-spot and flagellum of Euglena, by Mr. Wager; the biology and cytology of a new species of Fythium, by Dr. Trow; the biology of Acrospeira mirabilis, by Mr. Biffen; the histology and reproduction of the Laminariaceæ, and additional notes on the cytology of the reproductive cells in the Dictyotacer and Fucaceæ, by Mr. J. Lloyd Williams ; on the effect of salts on the $\mathrm{CO}_{2}$ assimilation of Ulva latissima, by Mr. Arber; on fungi found on the scale-insects of Ceylon, by Mr. Parkin; the structure and affinities of Dipteris conjugata, with notes on the geological history of the Dipteridinæe, by Mr. Seward and Miss Dale.

\section{RECORDING TELEPHONES.}

$\mathrm{NOW}$ that the telephone has become, even in this country, an instrument of such universal commercial and general employment, the advantages of an apparatus that will satisfactorily record the messages transmitted through an ordinary telephone line are so strikingly apparent that it is unnecessary to enlarge upon them. That it should have been possible to construct such an apparatus has been evident since the invention of the phonograph. But the direct combination of the phonograph with the telephone, which seems so simple in theory, has presented difficulties in practice which up to the present have not been successfully overcome, and the phonograph of to-day, over twenty years since its invention, remains little more than a scientific toy, whereas its contemporary, the telephone, has become an almost indispensable adjunct of civilisation. It would appear, however, that the problem of recording telephone messages is nearing a practical solution, for there have been quite recently put forward, under the names respectively of the "Telephonograph" and the "Telegraphone," two separate inventions of a recording telephone.

The first of these instruments--the "Telephonograph" -is the invention of Mr. E. O. Kumberg, and contains little that is novel in principle, being simply a combination of the phonograph with a loud-speaking telephone receiver, in which the inventor has sought by a suitable design of apparatus to diminish the distortion of voice which is usual with such an arrangement. The invention consists of a phonograph in which a loud-speaking telephone receiver is substituted in place of the ordinary diaphragm to which one speaks. The telephonic currents varying in the receiver set up vibrations in a soft iron diaphragm which is attached by a short stiff wire at its centre to a second diaphragm of mica. The centre of this mica diaphragm is connected by a link with the cutting style, which accordingly traces on the wax cylinder of the phonograph a record of the message transmitted through the telephone. The cylinder can then be subsequently used in connection with the speaking diaphragm of the phonograph to repeat the recorded message. Unfortunately, neither the telephone nor the phonograph is free from distortion, and the "Telephonograph" may be expected to possess in an enhanced degree the imperfection of each of its com. ponents; from what we learn, it seems that $\mathrm{Mr}$. Kumberg's invention is by no means perfect in articulation.

The second instrument which has been brought forward under the narne of the "Telegraphone" is, we believe, entirely new in its principle, and if it realises but a part of what is claimed for it by its inventor represents a very great advance in telephony. This instrument is the invention of Herr Valdemar Poulsen, a Danish electrician, and is on view at the Paris Exhibition. It is briefly described in a note contributed by Herr Poulsen to the Comptes rendus for June 25 , and somewhat more fully in an article which appears in the Revue Générale des Sciences for June 30.

It is, of course, perfectly well known that if a piece of steel be placed between the poles of an electromagnet which is excited by a current, a magnetic field is set up in the steel, the strength and direction of which depend upon the strength and direction of the current in the exciting coils of the electromagnet, and the magnetism thus induced in the steel is still retained by it when removed from the inducing magnetic field. This is the principle which Herr Poulsen has utilised in the construction of his new recording telephone. In place of the ordinary telephone receiver he uses a simple electromagnet, the current transmitted through the telephone line passing round the exciting coils of the magnet. When, therefore, any one speaks into the transmitting instrument at the far end of the telephone line, the magnetic field due to the electromagnet will vary in strength and direction in accordance with the varying electric currents transmitted through the lines. Between the poles of the magnet is passed a steel wire or band, which is moved forward in the direction of its length at a uniform and rapid velocity. At each point of this wire there will be produced a magnetisation proportional to the current which was flowing through the coils of the electromagnet at the moment when that section of the wire was passing between its poles. There will thus be established in the steel wire a magnetic record of the telephonic message, and just as the varying electric currents have been utilised to produce in the wire a magnetisation varying from point to point along its lenyth, so, by the converse process, may this magnetisation be employed to set up currents in a telephone

No. I607, vol. 62] 